\title{
Association between particulate matter and respiratory symptoms in students in the municipality of Guachetá, Colombia
}

Asociación entre material particulado y síntomas respiratorios en estudiantes del municipio

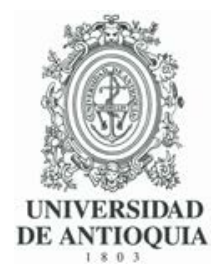
de Guachetá, Colombia

\author{
Bárbara J. Saavedra1 (iD) ${ }^{1}$, Andrés F. Sepúlveda (iD) ${ }^{1}$, Ronal J. Sierra (iD) 1, Luis C. Blanco-Becerra (iD)2 \\ ${ }^{1}$ Facultad de Ingeniería Ambiental. Universidad Santo Tomás. Carrera 9 \# 51-11. C. P. 110231. Bogotá D. C., Colombia. \\ ${ }^{2}$ Facultad de Economía. Universidad Santo Tomás. Carrera 9 \# 51-11. C. P. 110231. Bogotá D. C., Colombia.
}

\section{CITE THIS ARTICLE AS:}

B. J. Saavedra, A. F. Sepúlveda,

R. J. Sierra and L. C.

Blanco-Becerra. Association between particulate matter and respiratory symptoms in students in the municipality of Guachetá, Colombia, Revista

Facultad de Ingeniería Universidad de Antioquia, no. 104, pp. 168-177, Jul-Sep 2022. [Online]. [Online].

Available: https :

//www.doi.org/10.17533/

udea.redin. 20210954

\section{ARTICLE INFO:}

Received: September 29, 2020 Accepted: September 04, 2021 Available online: September 06, 2021

\section{KEYWORDS:}

Students; coal mining; air pollution; cross-sectional studies; signs and respiratory symptoms

Estudiante; industria del carbón; contaminación atmosférica; estudios transversales; signos y síntomas respiratorios
ABSTRACT: The purpose of this article was to establish the association between exposure to particulate matter and respiratory symptoms evaluated in students who remain in schools at the municipality of Guachetá (Colombia). This is a cross-sectional study conducted on children between 4 and 17 years old, in two schools in the municipality of Guachetá. During a period of 11 consecutive working days, using a personal sampling pump and a low-cost real-time sensor, concentrations of $P M_{10}$ and $P M_{2.5}$ were measured. A survey was applied to a sample of 276 students, obtaining respiratory symptoms and general data. A prevalence ratio (PR) was estimated to show the possible association between exposure to particulate matter and respiratory symptoms. The school with the highest concentrations of particulate matter presented a possible association with all the respiratory symptoms evaluated in the school facilities, with a PR of 3.05 (95\% Cl:1.62-5.76) for cough, 1.85 (95\% Cl:1.06-3.24) for phlegm, 5.12 (95\% Cl:2.17-12.07) for shortness of breath, 3.83 (95\% $\mathrm{Cl}: 2.07-7.10)$ for sneezing and 2.25 (95\% $\mathrm{Cl}: 1.12-4.54)$ for dry nasal passages. In conclusion, children who are located in the school closest to a coke furnace and disrepair roads where heavy traffic circulates, are possibly associated with the presence of respiratory symptoms during their stay in the school facilities. For living in the urban area, cooking with firewood or charcoal, and living with smokers at home, a possible association with the evaluated respiratory symptoms was found.

RESUMEN: Se estimó la posible asociación entre la exposición a material particulado medido en dos colegios del municipio de Guachetá (Colombia) y los síntomas respiratorios en los estudiantes entre los 4 y 17 años que permanecen en los colegios. x,Durante un periodo de 11 días hábiles consecutivos, se midieron las concentraciones de $P M_{10}$ y $P M_{2.5}$, empleando una bomba de muestreo personal y un sensor a tiempo real de bajo costo, respectivamente. Se aplicó una encuesta a una muestra de 276 estudiantes, obteniendo datos sobre los síntomas respiratorios. Se estimó una razón de prevalencias (RP), encontrando que el colegio con mayores concentraciones de material particulado presentó una posible asociación con todos los síntomas respiratorios evaluados en las instalaciones del colegio, con una RP de 3.05 (IC95 \%:1.62-5.76) para tos, 1.85 (IC95 \%:1.06-3.24) para flemas, 5.12 (IC95 \%:2.17-12.07) para dificultad para respirar, 3.83 (IC95 \%:2.07-7.10) para estornudos y 2.25 (IC95 \%:1.12-4.54) para resequedad en las fosas nasales. En conclusión, los estudiantes que se ubican en el colegio más cercano a una coquizadora y vías en mal estado por donde circula tráfico pesado, se asocian posiblemente con la presencia de síntomas respiratorios durante su permanencia en las instalaciones del colegio. El vivir en el casco urbano, cocinar con leña o carbón y convivir con fumadores en el hogar, también presentó una posible asociación con los síntomas respiratorios evaluados.

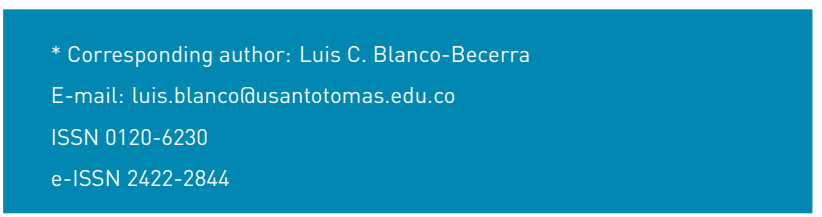

\section{Introduction}

Air pollution, which generates a negative impact on the health of the population, increases mortality 
and hospitalizations due to affectations mainly in the respiratory and cardiovascular systems [1, 2]. Adverse effects are observed in a higher percentage in susceptible populations such as children, who have a higher rate of inhalation, immature defenses and lungs, and are still developing immune systems [3, 4]. The most studied pollutants related to these diseases are particulate matter less than 10 microns $\left(P M_{10}\right)$ and less than 2.5 microns $\left(P M_{2.5}\right)$, due to their toxic effect on humans. These particles are made up of a mixture of matter in the solid and liquid state suspended in the air, which vary in size, shape and composition according to their origin [5].

In Colombia, development models favor the economic dimension and attract foreign investment to take advantage of the nation's natural resources. The country is attractive for investors from other countries interested in the exploitation of coal, which affects air quality [6]. Underground mining has processes such as mineral coking, which emits particulate matter that affects people inside the mines and in the area of external influence [7]. This is evident in the municipality of Guachetá, located in the province of Ubaté, in the department of Cundinamarca, $118 \mathrm{~km}$ north of Bogotá, where the coal coking activities located around the urban area pollute the air.

The municipality is one of the many places in the country that do not have an air quality surveillance system and have little information about the coal activity that takes place in the area. The exploitation of coal in Guachetá began approximately 45 years ago with family-type business units that have been maintained over the years. Those business units are largely informal and do not have any monitoring and environmental mitigation processes [8]. In some part, the problem of environmental deterioration comes from a lack of knowledge of people of the rules that the authorities in charge have established and also because of personal economic interests since it is the main source of livelihood [8]. By 2019, 30 mining titles and 108 mines, which operate 24 hours a day, were registered with the Mayor's Office and the mining unit of the municipality [9]. Taking into account this panorama, the present research established the possible association between exposure to particulate matter $\left(P M_{10}\right.$ and $\left.P M_{2.5}\right)$ and respiratory symptoms in students from two schools in the municipality of Guachetá, Colombia.

\section{Materials and methods}

A descriptive cross-sectional study was carried out in order to evaluate the exposure of students to particulate matter and the presence or absence of symptoms of respiratory disease in them. The research was conducted in two schools in the urban area of the municipality of Guachetá. The first is the high school headquarters (grades six to eleven) of the departmental educational institution El Carmen with a population of 488 students. It is surrounded by a main unpaved road that leads to the municipality of Lenguazaque, the heavy vehicles used to transport coal pass through the area, and three rods with little vehicles traffic. In addition, the institution is located near a coke furnace. The second educational institution is the Gonzalo Jiménez School, which houses grades zero to fifth, with a population of 481 students. The school has only one pedestrian traffic lane attached. The institution is located next to a restaurant on the southwestern side; there is a kitchen that works with firewood, whose chimney overlooks the school park (Figure 1).

The sample of students was selected under a stratified random sampling, dividing the students according to their level of education, from grade 0 to 11 . Students who had lived in the municipality for more than two years were chosen. Children were in a range between 4 and 17 years old and included those who were healthy and those who presented symptoms related to respiratory diseases. The sample size was 276 students with a level of confidence of $95 \%$. With the updated lists for each stratum (grade), a simple random sampling was applied to obtain the students who would be surveyed by course.

This study was classified as an analysis without risk, according to the provisions of Article 11 of Resolution 8430 of 1993 of the Colombian Ministry of Health. The children who were surveyed agreed to participate in the study by signing an informed consent. For primary school, the survey was answered by the guardian and the child, while in secondary, it was completed by the students. General data, family history and symptoms related to acute respiratory diseases (coughing, sneezing, shortness of breath, throat irritation, phlegm, and dry nasal passages) evidenced within the school facilities were searched for. The respiratory symptoms sought with the survey were obtained from the National Environmental Health Survey, prepared by the Ministry of Health and Social Protection of Colombia.

\subsection{Particulate matter measurement}

For $P M_{10}$ measurement, a GilAir-3 brand volumetric flow personal sampling pump was used, which had a flow rate of $1500 \mathrm{cc} / \mathrm{min}$. This pump was connected, through a tube, to a cyclone that filters $P M_{10}$, so that it was retained in a PVC filter, to then determine the concentration of particles by means of the gravimetric method [10]. Regarding the measurement of $P M_{2.5}$, real-time monitoring was carried out with the Airbeam equipment, recognized within the emerging technology of low-cost air sensors. Using a light scattering method, it quantifies fine particles (PM2.5), relative humidity $(\mathrm{RH})$, and temperature with $r=0.65$ [11]. 

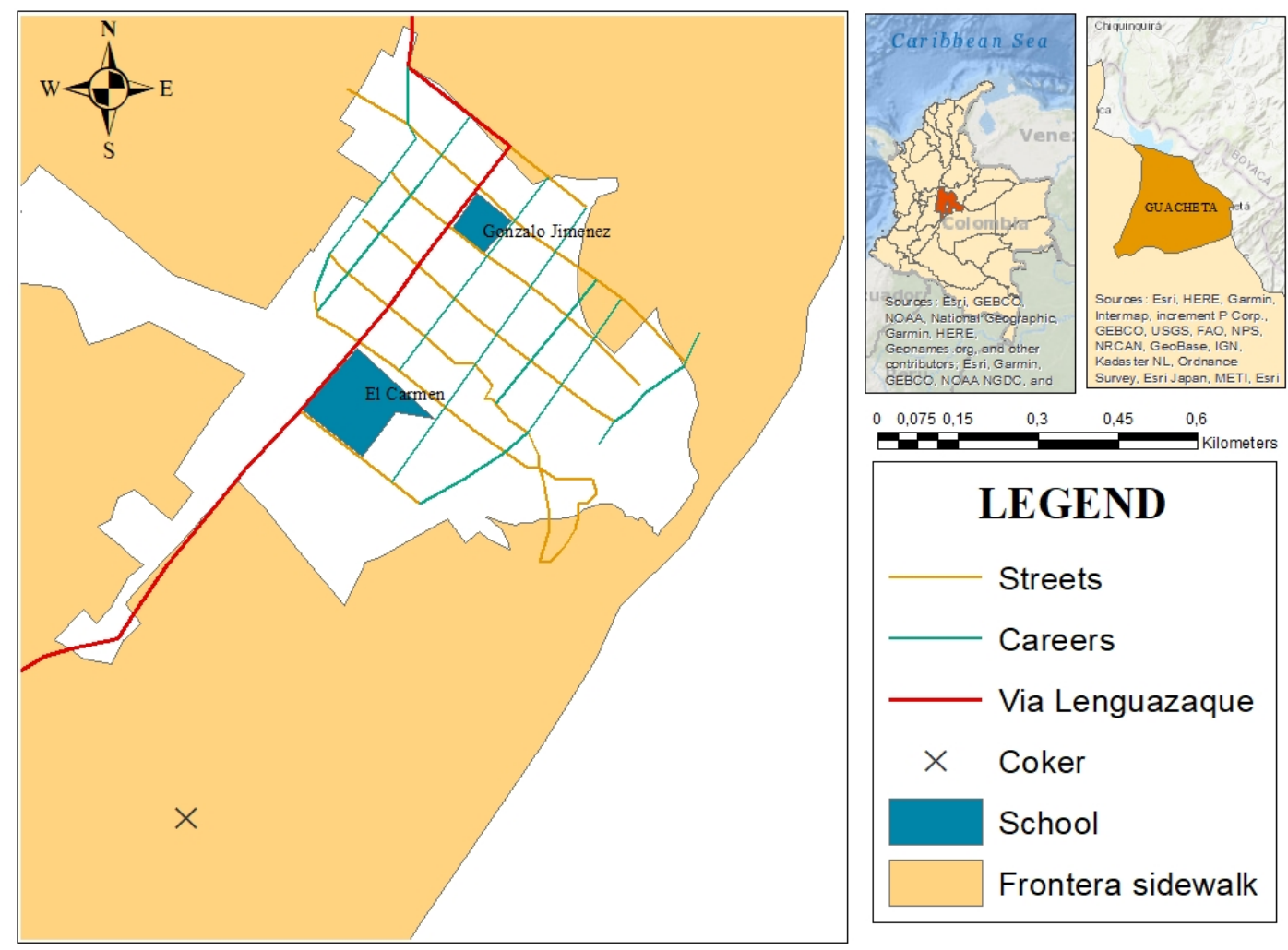

Figure 1 Urban districts in the municipality of Guachetá and location of the El Carmen and Gonzalo Jiménez schools 2019

The concentrations of the pollutants were reported at reference conditions $\left(25^{\circ} \mathrm{C}\right.$ and $\left.101,325 \mathrm{kPa}\right)$.

To select the sampling points, the schools were explored previously using the Airbeam. With it, the points with the highest concentration of $P M_{2.5}$ were identified. The monitoring equipment was positioned at a height of 1.5 meters from the ground, attached to a tripod, where no obstacles were located within a radius of 2 meters. These instruments were guarded by the researchers, in order to avoid accidents due to any manipulation attempted by the students.

The monitoring was conducted between August 30th and September 13th, 2019. No measurements were taken on weekends due to school policies. The sampling was run simultaneously in each school for 11 consecutive working days, between 7 a.m. and 1 p.m. Data from meteorological stations were not used because the closest station was in the municipality of Ráquira. Therefore, the data could not be extrapolated due to orographic conditions.

\subsection{Analysis of data}

A descriptive analysis of the variables of interest obtained in the surveys was carried out, as well as the concentrations of particulate matter registered by the personal sampling equipment. For the concentrations obtained from the monitoring equipment, correlations were calculated between the two schools and the days of sampling in each school. At the same time, equality or difference of variances and means between the monitoring days in each institution were estimated. The prevalence ratio (PR) was estimated to detect the possible associations between the presence of respiratory symptoms and the concentrations of particulate material, the proximity of the houses to mines, the use of wood ovens, and other possible variables. Additionally, a logistic regression was carried out with each one of the variables obtained in the survey and the respiratory symptoms of the children. For the calculation of logistic regression, correlations and difference of variances and means, the Stata 11 program was used, while, for PR, the EPI INFO 7.2.3.1 software was used. 


\section{Results}

\subsection{General characteristics}

Out of the 969 students enrolled in both schools, a representative sample of 276 students was taken. The sample had a loss of $25 \%$, due to the fact that some students withdrew from the institutions or the parents did not agree to participate in the study. Finally, 120 students from the El Carmen School and 87 from the Gonzalo Jiménez institution participated. Among those surveyed, men and women each accounted for $50 \%$ of the population. In the El Carmen school, the average age was 13.82 years (SD: \pm 1.87 , while in Gonzalo Jiménez it was 8.21 years (SD: \pm 2.09 ). Out of the total, $60.9 \%$ of those students surveyed live in urban areas, $11 \%$ live near a mine, $26.1 \%$ cook with firewood and $20.8 \%$ live with smokers inside their homes. Regarding the respiratory symptoms exhibited by the children within the school facilities, coughing occurred in $74.4 \%$ of the students, followed by sneezing, with $71.1 \%$, in third place, phlegm was present, with $50.2 \%$, dry nasal passages, with $22.7 \%$, and, finally, shortness of breath, with $18.8 \%$. The percentage of reported symptoms was always higher at the El Carmen School, compared to the Gonzalo Jiménez School (Table 1).

\subsection{Particulate matter concentrations}

The daily average of $P M_{10}$ in the El Carmen School was $190.47 \mu \mathrm{g} / \mathrm{m}^{3}$, while the Gonzalo Jiménez institution presented a value of $190.29 \mu \mathrm{g} / \mathrm{m}^{3}$. For $P M_{2.5}$, the daily average of six hours in the El Carmen School was $8.37 \mu \mathrm{g} / \mathrm{m}^{3}$, higher than the average found in Gonzalo Jiménez, which was $6.91 \mu \mathrm{g} / \mathrm{m}^{3}$ (table 2). The correlation for $P M_{10}$ and $P M_{2.5}$ between schools was -0.26 and -0.07 , respectively, which is statistically significant. When the correlation analysis between the days of measurement in each school was conducted, it was evidenced that there is a positive correlation. In addition, equal variances and means of concentration were shown between schools, which were statistically significant.

The values obtained for $P M_{10}$ in the monitoring always exceeded the guideline value of air quality for 24 hours $\left(50 \mu \mathrm{g} / \mathrm{m}^{3}\right)$ of the World Health Organization (WHO); for $P M_{2,5}$ the values did not exceed the guideline value for 24 hours $\left(25 \mu \mathrm{g} / \mathrm{m}^{3}\right)$, although it was only exceeded on one occasion at the Gonzalo Jiménez school. As for the hours with the highest concentration of $P M_{2.5}$, these were traced to the first hours of the day for the two schools, and were higher in the Gonzalo Jiménez School (Figure 2). Indeed, during these hours, productive coal coking activities are carried out.

\subsection{Relationship between respiratory symptoms in students within school facilities and particulate matter exposure, among other variables}

Evaluating the presence of respiratory symptoms in schools, it was evidenced that the school with the highest concentrations of particulate matter (El Carmen) presented a possible association with symptoms of shortness of breath, sneezing, coughing, dry nasal passages and phlegm, in comparison with the school that has lower concentrations of particulate matter (Gonzalo Jiménez), all of which are statistically significant.

When the sex variable was evaluated, a possible association with phlegm, shortness of breath, and sneezing was found for the female sex, while the symptoms of coughing and dry nasal passages are possibly associated with the male sex. For the variable living near a mine, a possible association with the symptom of shortness of breath was found. As for cooking with firewood, a potential association with the symptoms of coughing, phlegm, sneezing and dry nasal passages was evidenced. Finally, for the variables living in the urban area and smokers at home, a possible association was found with the five respiratory symptoms studied (Table 3). When performing the logistic regression, it was evidenced that all the respiratory symptoms studied presented a statistically significant relationship in the models that included the children's school, corroborating what was calculated in the PR (Table 3). The presence of symptoms in children was explained by each model between $7 \%$ and 16\% (Table 4).

When the analysis in each school was conducted, a coincidence was evidenced regarding the general analysis. Thus, symptoms of phlegm and sneezing are possibly related to the female sex, while living near a land mine may be associated with shortness of breath and having phlegm and dry nasal passages are potentially associated with cooking with wood. Having a smoker at home is possibly associated with coughing, shortness of breath, and sneezing, and, finally, living in the urban area is associated with the presence of the five respiratory symptoms evaluated (Table 5).

The logistic regression showed that the variable place of residence was related to the symptoms of phlegm, sneezing, and cough, only in the Gonzalo Jiménez School, being statistically significant. The estimated models explained between 6 to $8 \%$ of the presence of the corresponding symptom. 
Table 1 Demographic characteristics and risk factors of school students

\begin{tabular}{llllll}
\hline \multirow{2}{*}{ Variables } & & \multicolumn{2}{l}{$\begin{array}{l}\text { El Carmen } \\
\text { n } \%\end{array}$} & \multicolumn{3}{c}{$\begin{array}{c}\text { Gonzalo Jiménez } \\
\text { n } \%\end{array}$} \\
\hline \multirow{2}{*}{ Sex } & Male & 63 & 52.5 & 42 & 48.3 \\
& Female & 57 & 47.5 & 45 & 51.7 \\
\hline \multirow{2}{*}{ Age } & 4-11 years old & 12 & 10.0 & 84 & 96.6 \\
& 12-17 years old & 108 & 90.0 & 3 & 3.4 \\
\hline Place of & Rural district & 54 & 45.0 & 27 & 31.1 \\
residence & Urban area & 66 & 55.0 & 60 & 68.9 \\
\hline Living near & Yes & 13 & 10.8 & 10 & 11.5 \\
a mine & No & 107 & 89.2 & 77 & 88.5 \\
\hline Cooking with & Yes & 41 & 34.2 & 13 & 14.9 \\
firewood & No & 79 & 65.8 & 74 & 85.1 \\
\hline Smokers at & Yes & 29 & 24.2 & 17 & 16.1 \\
home & No & 91 & 75.8 & 73 & 83.9 \\
\hline \multirow{2}{*}{ Cough } & Yes & 100 & 3.3 & 54 & 62.1 \\
& No & 20 & 16.8 & 33 & 37.9 \\
\hline \multirow{2}{*}{ Phlegm } & Yes & 68 & 56.7 & 36 & 41.4 \\
& No & 52 & 43.3 & 51 & 58.6 \\
\hline Shortness of & Yes & 33 & 27.5 & 6 & 6.9 \\
breath & No & 87 & 72.5 & 81 & 93.1 \\
\hline \multirow{2}{*}{ Sneezing } & Yes & 99 & 82.5 & 48 & 55.2 \\
& No & 21 & 17.5 & 39 & 44.8 \\
\hline Dry nasal & Yes & 34 & 28.3 & 13 & 14.9 \\
passages & No & 86 & 71.7 & 74 & 85.1 \\
\hline
\end{tabular}

$\mathrm{n}$ : number of students surveyed

Table $2 \mathrm{PM}_{10}$ and $\mathrm{PM}_{2.5}$ concentrations in El Carmen and Gonzalo Jiménez schools for a period of 6 hours during the 11 -day monitoring

\begin{tabular}{l|llllllll}
\hline School & Pollutant & Median & SD & Min & P25 & P50 & P75 & Max. \\
\hline El Carmen & $\mathrm{PM}_{10}\left(\mu \mathrm{g} / \mathrm{m}^{3}\right)$ & 190.47 & 152.24 & 60.18 & 63.84 & 181.81 & 262.29 & 570.15 \\
& $\mathrm{PM}_{2.5}\left(\mu \mathrm{g} / \mathrm{m}^{3}\right)$ & 8.37 & 4.67 & 2.69 & 4.94 & 6.70 & 10.66 & 23.93 \\
\hline Gonzalo & $\mathrm{PM}_{10}\left(\mu \mathrm{g} / \mathrm{m}^{3}\right)$ & 190.29 & 202.20 & 62.36 & 63.03 & 127.65 & 187.89 & 768.23 \\
Jimenez & $\mathrm{PM}_{2.5}\left(\mu \mathrm{g} / \mathrm{m}^{3}\right)$ & 6.91 & 9.04 & 0.17 & 1.22 & 2.49 & 8.89 & 44.55 \\
\hline
\end{tabular}

*standard deviation; Min: 1st percentile; P25: 25th percentile; P50: median of the sample; P75: 75th percentile; Max: 99th percentile

\section{Discussion}

The present study found a possible association between the respiratory symptoms registered in the students during the school day, with the concentrations of particulate matter evaluated in the institutions coming from a coke furnace located a few kilometers from the municipality and from heavy-duty trucks and resuspended dust in the roads inside Guachetá. It was observed that the El Carmen School, located near fixed and mobile sources, had a higher prevalence of all respiratory symptoms and levels of particulate matter, compared to the Gonzalo Jiménez
School. This scenario has not been evaluated in any other research in Colombia, being this, the first study to examine this in a small-scale mining activity, which is replicated in many municipalities in Colombia.

In Bogotá capital of Colombia, concentrations of $P M_{10}$ were characterized, eight hours a day, in three district schools located near roads with high vehicular traffic, and one school attached to a road in a semi-rural zone, in which values were found in a range between 55 and $91 \mu \mathrm{g} / \mathrm{m}^{3}$ [12], lower than those registered in the present study; the difference in the concentrations 


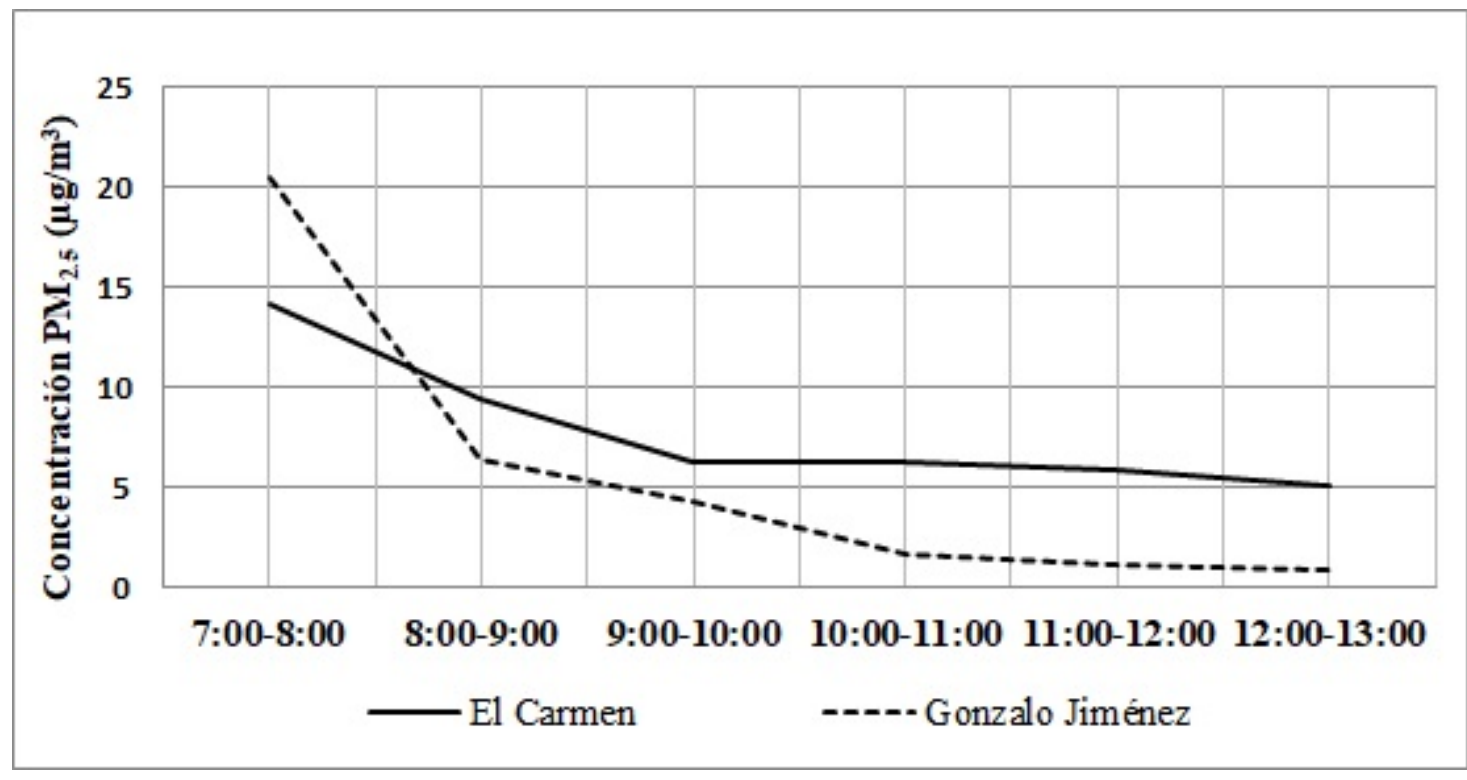

Figure 2 Average hourly concentration of $P M_{2.5}$ during the 11 days of monitoring at the El Carmen and the Gonzalo Jiménez schools

Table 3 Prevalence ratio (PR) between the presence of respiratory symptoms with school, proximity to mines, place of residence, cooking with firewood, and smokers at home

\begin{tabular}{|c|c|c|c|c|c|c|}
\hline Variable & & $\begin{array}{c}\text { Coughing } \\
\text { PR } \\
\text { (CI95\%) }\end{array}$ & $\begin{array}{c}\text { Phlegm } \\
\text { PR } \\
\text { (CI95\%) }\end{array}$ & $\begin{array}{c}\text { SB } \\
\text { PR } \\
\text { (CI95\%) }\end{array}$ & $\begin{array}{c}\text { Sneezing } \\
\text { PR } \\
\text { (CI95\%) }\end{array}$ & $\begin{array}{c}\text { DP } \\
\text { PR } \\
(\mathrm{C} 195 \%) \\
\end{array}$ \\
\hline School & $\begin{array}{l}\text { El Carmen } \\
\text { Gonzalo } \\
\text { Jiménez }\end{array}$ & $\begin{array}{c}3.05 \\
(1.62-5.76)^{*}\end{array}$ & $\begin{array}{c}1.85 \\
(1.06-3.24)^{*}\end{array}$ & $\begin{array}{c}5.12 \\
(2.17-12.07)^{*}\end{array}$ & $\begin{array}{c}3.83 \\
(2.07-7.10)^{*}\end{array}$ & $\begin{array}{c}2.25 \\
(1.12-4.54)^{*}\end{array}$ \\
\hline Sex & $\begin{array}{l}\text { Female } \\
\text { Male }\end{array}$ & $\begin{array}{c}0.91 \\
(0.49-1.71) \\
\end{array}$ & $\begin{array}{c}0.91 \\
(0.49-1.71) \\
\end{array}$ & $\begin{array}{c}1.10 \\
(0.55-2.22) \\
\end{array}$ & $\begin{array}{c}1.27 \\
(0.70-2.33) \\
\end{array}$ & $\begin{array}{c}0.98 \\
(0.51-1.89) \\
\end{array}$ \\
\hline $\begin{array}{l}\text { Place of } \\
\text { residence }\end{array}$ & $\begin{array}{c}\text { Urban } \\
\text { Rural district }\end{array}$ & $\begin{array}{c}1.73 \\
(0.92-3.25)\end{array}$ & $\begin{array}{c}1.88 \\
(1.07-3.30)^{*}\end{array}$ & $\begin{array}{c}1.57 \\
(0.74-3.30)\end{array}$ & $\begin{array}{c}1.70 \\
(0.93-3.14)\end{array}$ & $\begin{array}{c}1.69 \\
(0.85-3.41)\end{array}$ \\
\hline $\begin{array}{l}\text { Living near } \\
\text { a mine }\end{array}$ & $\begin{array}{l}\text { Yes } \\
\text { No }\end{array}$ & $\begin{array}{c}0.60 \\
(0.24-1.51)\end{array}$ & $\begin{array}{c}0.89 \\
(0.38-2.14)\end{array}$ & $\begin{array}{c}1.61 \\
(0.59-4.39)\end{array}$ & $\begin{array}{c}0.40 \\
(0.17-0.93)\end{array}$ & $\begin{array}{c}0.94 \\
(0.33-2.69)\end{array}$ \\
\hline $\begin{array}{l}\text { Cooking with } \\
\text { firewood }\end{array}$ & $\begin{array}{l}\text { Yes } \\
\text { No }\end{array}$ & $\begin{array}{c}1.12 \\
(0.54-2.30)\end{array}$ & $\begin{array}{c}1.33 \\
(0.71-2.49)\end{array}$ & $\begin{array}{c}0.82 \\
(0.36-1.86)\end{array}$ & $\begin{array}{c}1.60 \\
(0.78-3.30)\end{array}$ & $\begin{array}{c}1.27 \\
(0.62-2.62)\end{array}$ \\
\hline $\begin{array}{c}\text { Smokers at } \\
\text { home }\end{array}$ & $\begin{array}{l}\text { Yes } \\
\text { No }\end{array}$ & $\begin{array}{c}2.00 \\
(0.84-4.78)\end{array}$ & $\begin{array}{c}1.18 \\
(0.60-2.31)\end{array}$ & $\begin{array}{c}1.41 \\
(0.62-3.18)\end{array}$ & $\begin{array}{c}1.45 \\
(0.66-3.16)\end{array}$ & $\begin{array}{c}1.43 \\
(0.67-3.06)\end{array}$ \\
\hline
\end{tabular}

* $p<0.050$; PR: Prevalence Ratio; 95\% Cl: 95\% confidence interval; SB: shortness of breath; DNP: dry nasal passages.

recorded between the studies can be explained in relation to the emission sources of the zones. For example, the emissions derived from heavy-duty trucks and the resuspended dust, product of not paving the main road that leads to the municipality of Lenguazaque, located next to the El Carmen School. Additionally, the sampling sites, which were located outdoors (sports court and park), can be affected by cleaning activities and the continuous movement of students in the institutions.
Regarding the 6-hour average concentrations of $P M_{2.5}$ recorded in our study $\left(6.91\right.$ and $\left.8.37 \mu \mathrm{g} / \mathrm{m}^{3}\right)$, these do not exceed the daily value established by the WHO, although they are higher than those evidenced in other studies, such as the one conducted in Spanish educational institutions, which registered average concentrations of 1.70 and $3.60 \mu \mathrm{g} / \mathrm{m}^{3}$, in which real-time measuring equipment was used [13]. The $P M_{2.5}$ values obtained in our work may have as their origin the chimney of the restaurant located in front of the Gonzalo Jiménez school patio, while, for $\mathrm{El}$ 
Table 4 Logistic regression for symptoms and variables in all the students

\begin{tabular}{cccccc}
\hline Symptom & Variable & $\mathrm{B}$ & $\mathrm{Sig}$ & Exp (B) & $\begin{array}{c}R^{2} \text { of } \\
\text { Nagelkerke }\end{array}$ \\
\hline \multirow{2}{*}{ Coughing } & School & 1.265 & 0.000 & 3.544 & \multirow{2}{*}{0.117} \\
& Place of residence & -0.789 & 0.022 & 0.454 & \\
\hline \multirow{2}{*}{ Phlegm } & School & 0.650 & 0.031 & 1.916 & \multirow{2}{*}{0.103} \\
& Place of residence & -1.264 & 0.01 & 0.282 & \\
\hline \multirow{2}{*}{ Shortness of breath } & School & -0.960 & 0.025 & 0.383 & \multirow{2}{*}{0.116} \\
& Place of residence & 1.633 & 0.001 & 5.121 & \\
\hline \multirow{2}{*}{ Sneezing } & School & 1.514 & 0.000 & 4.543 & \multirow{2}{*}{0.159} \\
& Place of residence & -0.842 & 0.014 & 0.431 & \\
\hline
\end{tabular}

Table 5 Prevalence ratio (PR) between the presence of respiratory symptoms with proximity to mines, place of residence, cooking with firewood, and smokers at home, in the El Carmen and Gonzalo Jiménez schools

\begin{tabular}{|c|c|c|c|c|c|c|}
\hline \multicolumn{2}{|c|}{ El Carmen School } & $\begin{array}{c}\text { Coughing } \\
\text { PR } \\
\text { (CI95\%) }\end{array}$ & $\begin{array}{l}\text { Phlegm } \\
\text { PR } \\
\text { (CI95\%) }\end{array}$ & $\begin{array}{c}\text { SB } \\
\text { PR } \\
(\mathrm{Cl} 95 \%)\end{array}$ & $\begin{array}{l}\text { Sneezing } \\
\text { PR } \\
\text { (CI95\%) }\end{array}$ & $\begin{array}{c}\text { DP } \\
\text { PR } \\
\text { (C195\%) }\end{array}$ \\
\hline Sex & $\begin{array}{l}\text { Female } \\
\text { Male }\end{array}$ & $\begin{array}{c}1.13 \\
(0.43-2.97)\end{array}$ & $\begin{array}{c}1.10 \\
(0.53-2.27)\end{array}$ & $\begin{array}{c}1.25 \\
(0.56-2.79)\end{array}$ & $\begin{array}{c}1.25 \\
(0.48-3.25)\end{array}$ & $\begin{array}{c}0.75 \\
(0.34-1.70)\end{array}$ \\
\hline $\begin{array}{l}\text { Place of } \\
\text { residence }\end{array}$ & $\begin{array}{c}\text { Urban } \\
\text { Rural district }\end{array}$ & $\begin{array}{c}1.62 \\
(0.62-4.25)\end{array}$ & $\begin{array}{c}1.88 \\
(0.91-3.92)\end{array}$ & $\begin{array}{c}1.63 \\
(0.72-3.73)\end{array}$ & $\begin{array}{c}1.81 \\
(0.70-4.67)\end{array}$ & $\begin{array}{c}1.95 \\
(0.85-4.50)\end{array}$ \\
\hline $\begin{array}{l}\text { Living near } \\
\text { a mine }\end{array}$ & $\begin{array}{l}\text { Yes } \\
\text { No }\end{array}$ & $\begin{array}{c}0.40 \\
(0.11-1.40)\end{array}$ & $\begin{array}{c}0.62 \\
(0.20-1.97)\end{array}$ & $\begin{array}{c}1.76 \\
(0.54-5.80)\end{array}$ & $\begin{array}{c}0.43 \\
(0.12-1.50)\end{array}$ & $\begin{array}{c}1.20 \\
(0.34-4.20)\end{array}$ \\
\hline $\begin{array}{l}\text { Cooking with } \\
\text { firewood }\end{array}$ & $\begin{array}{l}\text { Yes } \\
\text { No }\end{array}$ & $\begin{array}{c}0.96 \\
(0.35-2.63)\end{array}$ & $\begin{array}{c}1.12 \\
(0.52-2.42)\end{array}$ & $\begin{array}{c}0.64 \\
(0.27-1.56)\end{array}$ & $\begin{array}{c}1.37 \\
(0.49-3.85)\end{array}$ & $\begin{array}{c}1.14 \\
(0.49-2.65)\end{array}$ \\
\hline $\begin{array}{c}\text { Smokers at } \\
\text { home }\end{array}$ & $\begin{array}{l}\text { Yes } \\
\text { No }\end{array}$ & $\begin{array}{c}1.33 \\
(0.41-4.37)\end{array}$ & $\begin{array}{c}0.93 \\
(0.40-2.15) \\
\end{array}$ & $\begin{array}{c}1.26 \\
(0.50-3.14)\end{array}$ & $\begin{array}{c}1.02 \\
(0.34-3.10)\end{array}$ & $\begin{array}{c}1.56 \\
(0.63-3.83) \\
\end{array}$ \\
\hline Gonzalo Jim & énez school & $\begin{array}{l}\text { Coughing } \\
\text { PR } \\
\text { (CI95\%) }\end{array}$ & $\begin{array}{l}\text { Phlegm } \\
\text { PR } \\
\text { (CI95\%) }\end{array}$ & $\begin{array}{c}\text { SB } \\
\text { PR } \\
\text { (CI95\%) }\end{array}$ & $\begin{array}{l}\text { Sneezing } \\
\text { PR } \\
\text { (CI95\%) }\end{array}$ & $\begin{array}{c}\text { DP } \\
\text { PR } \\
\text { (CI95\%) }\end{array}$ \\
\hline Sex & $\begin{array}{c}\text { Female } \\
\text { Male }\end{array}$ & $\begin{array}{c}0.83 \\
(0.35-1.99)\end{array}$ & $\begin{array}{c}1.07 \\
(0.46-2.54)\end{array}$ & $\begin{array}{c}0.93 \\
(0.18-4.92)\end{array}$ & $\begin{array}{c}1.50 \\
(0.64-3.52)\end{array}$ & $\begin{array}{c}2.38 \\
(0.68-8.25)\end{array}$ \\
\hline $\begin{array}{l}\text { Place of } \\
\text { residence }\end{array}$ & $\begin{array}{c}\text { Urban } \\
\text { Rural district }\end{array}$ & $\begin{array}{c}2.91 \\
(1.15-7.38)^{*}\end{array}$ & $\begin{array}{c}2.67 \\
(0.99-7.17)^{*}\end{array}$ & SD & $\begin{array}{c}2.94 \\
(1.16-7.45)^{*}\end{array}$ & $\begin{array}{c}2.81 \\
(0.60-13.06)\end{array}$ \\
\hline $\begin{array}{l}\text { Living near } \\
\text { a mine }\end{array}$ & $\begin{array}{l}\text { Yes } \\
\text { No }\end{array}$ & $\begin{array}{c}0.91 \\
(0.23-3.51)\end{array}$ & $\begin{array}{c}1.48 \\
(0.40-5.57)\end{array}$ & $\begin{array}{c}1.60 \\
(0.17-15.19)\end{array}$ & $\begin{array}{c}0.30 \\
(0.08-1.21)\end{array}$ & $\begin{array}{c}0.60 \\
(0.07-5.16)\end{array}$ \\
\hline $\begin{array}{l}\text { Cooking with } \\
\text { firewood }\end{array}$ & $\begin{array}{l}\text { Yes } \\
\text { No }\end{array}$ & $\begin{array}{c}0.67 \\
(0.20-2.20)\end{array}$ & $\begin{array}{c}1.26 \\
(0.38-4.13)\end{array}$ & SD & $\begin{array}{c}0.94 \\
(0.29-3.09)\end{array}$ & $\begin{array}{c}1.04 \\
(0.20-5.40)\end{array}$ \\
\hline $\begin{array}{c}\text { Smokers at } \\
\text { home }\end{array}$ & $\begin{array}{l}\text { Yes } \\
\text { No }\end{array}$ & $\begin{array}{c}2.56 \\
(0.67-9.70)\end{array}$ & $\begin{array}{c}1.52 \\
(0.48-4.79)\end{array}$ & $\begin{array}{c}1.05 \\
(0.11-9.83)\end{array}$ & $\begin{array}{c}1.57 \\
(0.48-5.14)\end{array}$ & $\begin{array}{c}0.94 \\
(0.18-4.83)\end{array}$ \\
\hline
\end{tabular}

${ }^{*} \mathrm{p}<$ <.050; PR: prevalence ratio; 95\% Cl: 95\% confidence interval; SB: shortness of breath; DNP: dry nasal passages; ND: no data

Carmen, the data is represented by the traffic, mainly, of heavy-duty trucks on the main avenue and by the coke furnace located a few kilometers from the school.

Epidemiological studies carried out in the last decade have shown that the effects of particulate matter in its breathable fraction are manifested mainly in irritation of the eyes and the respiratory tract [14]. The present research showed that the school with the highest concentrations of PM10 had a higher prevalence of all respiratory symptoms, which coincides with a study carried out in Kajang (Malaysia), which identified a possible association between exposure to $P M_{10}$ and $P M_{2.5}$ in schools located near heavy traffic roads and the coughing $(P R=10.24)$ and shortness of breath $(P R=8.31)$ symptoms [15].

In Jinan (China), the association between exposure to $P M_{2.5}$ and symptoms in school children was sought. 
That study found that, due to the increase of $10 \mu \mathrm{g} / \mathrm{m}^{3}$ of the pollutant, the Odds Ratio (OR) was 1.02 for coughing and 1.03 for sneezing [16]. In Colombia, Rodríguez et al. found that, in preschoolers who lived in areas with high levels of $P M_{10}$, the symptoms of sneezing and phlegm had an incidence rate of 1.20 and 1.05, respectively [17]. In Bogotá, in 2007, it was observed that children under five years of age who attended a kindergarten in the town of Puente Aranda with an average concentration of $P M_{10}$ of $91 \mu \mathrm{g} / \mathrm{m}^{3}$, presented an incidence rate ratio (IRR) of 1.3 for phlegm and 1.1 for coughing, compared to the kindergarten with the lowest level of the contaminant $\left(50 \mu \mathrm{g} / \mathrm{m}^{3}\right)$ [18]. Years later, in five localities in the same city, a relationship between coughing symptoms and exposure was found with higher levels of air pollution in children under five years of age who attended kindergartens with an IRR of 1.23. These kindergartens were located at a distance of less than 100 $\mathrm{m}$ from the main fixed or mobile sources, as well as roads in poor condition, high traffic flow roads, chimneys, and industrial estates [19].

Finally, regarding carbon emissions exposure, Álvarez et al. evaluated respiratory symptoms and lung function in children between 6 and 14 years of age who lived in areas exposed and not exposed to $P M_{10}$ derived from coal loading. It was evidenced that the infants who lived in the areas of greater exposure had upper respiratory tract symptoms (nasal congestion, itching, sneezing, rhinorrhea, and epiphora), with an OR of 2.18 [20].

Exposure to $P M_{2.5}$ is related to emissions derived from the combustion of vehicular traffic, in addition to mining production processes. This pollutant can be deposited in the lung alveoli and trigger an inflammatory response and shortness of breath [21]; it can also pass into the bloodstream, becoming a cause of diseases such as asthma [22], cerebrovascular accidents, heart disease, lung cancer, among others [23].

With regard to sex, the present research found that being a woman is potentially associated with the symptoms of phlegm, shortness of breath, and sneezing. Thus, the evidence in Hong Kong is corroborated, regarding the association between high levels of air pollution and the presence of phlegm in girls between the ages of 8 and 13 who were studying in schools in that city $(O R=1.44)$ [24].

For the variables related to the location and housing conditions of the students, it was observed that residing in the urban area of Guachetá is possibly associated with the five symptoms evaluated. This confirms what was evidenced in Vietnam, in rural and urban areas, where sputum or phlegm was presented in a higher proportion in urban areas (16\%) than in rural areas (11\%) [25]. In
Colombia, in five coal-bearing municipalities of the Cesar department, after evaluating respiratory symptoms and possible associated factors in children under 12 years of age, a relationship was found between children who lived in households where they cooked with firewood or charcoal and the presence of nocturnal dry cough IOR = 1.34), compared to those who lived in houses that cooked with another fuel [26].

For the symptom of phlegm, in the present research, a possible association of this with cooking with firewood and the presence of smokers at home was found. The latter was also related to symptoms of shortness of breath ( $P R=1.41)$ and coughing ( $P R=2)$. In Wuhan (China), the association between seventh-grade children living with smokers and symptoms of coughing (OR $=1.19$ ) and phlegm (OR $=1.60)$, as well as the use of coal as fuel with coughing $(O R=1.04)$ and phlegm $(O R=1.12)$ were observed [27]. On the other hand, in Italy, there is a relationship between women exposed to secondhand smoke and the respiratory symptoms of cough (OR =1.52) and shortness of breath $(O R=2.91)$ [28]; in Romania, passive smokers were associated with the presence of symptoms in asthmatics such as shortness of breath IOR $=2.87$ ) and allergies in children with symptoms such as sneezing, coughing, presence of phlegm, dry nasal passages $(O R=5.18)$. Furthermore, the study linked stoves that use wood and charcoal as fuel with the presence of symptoms associated with allergies (OR $=1.91$ ) [29].

One weakness evidenced by this research was the reason why some of the students from the Gonzalo Jiménez School did not participate, in the cases in which the survey was completed by father and son. Due to the fact that one of the main economic activities in the municipality is coal mining, some parents denied permission to their children because of their own interests. This was mitigated by the selection of more students also randomly, in order to cover a representative sample in the analysis of results. On the other hand, a child's daily exposure to air pollution is the sum of exposure to various microenvironments throughout the day. However, our study only had access to the school. The use of low-cost air sensors leads to a possible bias in the accuracy of air quality measurements. However, its use to observe trends in the behavior of the pollutant has been used in other studies [30], thus minimizing this bias. Finally, the lack of meteorological data in the study area can influence the possible association found in each of the schools. Nonetheless, taking the municipality as the unit of analysis shows that the population is exposed to emissions from the nearest coal mine, which is confirmed in the answers of all students of the school in their lower and upper grades.

However, although the purpose of the study was to 
establish the presence of respiratory symptoms in students in the school facilities, household conditions that could influence the presence of symptoms were also evaluated. This provided a broader picture of the situation of the minors. Another strong point of the study was the use of measurement equipment in real time and by gravimetric method. Thanks to these, a better assessment of exposure was obtained in school facilities. Low-cost emerging sensors have been used in other studies, showing a good correlation between environmental measurement and the one obtained with personal measurement equipment in real time [30].

\section{Conclusions}

The findings of the present study show a possible association between the concentrations of particulate matter and respiratory symptoms in children under 17 years who attend two educational centers in the municipality of Guachetá. There, emissions from coal coking and the condition of the local road network are possibly associated with the prevalence of coughing, phlegm, shortness of breath, sneezing, and dry nasal passages. These types of scenarios are constantly presented in many municipalities in Colombia. However, since they are not very significant, they are not evaluated. That situation leads to long-term health problems for the population. Additionally, the location of roads in poor condition where heavy cargo vehicles circulate influences the presence of respiratory symptoms. For this reason, educational centers and other types of facilities that house vulnerable populations should be located far from these sources of exposure. In this sense, residential land uses, and the location of schools must be reviewed and adjusted according to the environmental impact that the coal industry may cause within the municipality.

Finally, the information resulting from this research provides evidence that allows the generation of prevention actions, which must be directed by the competent health and environment institutions of Guachetá, in order to promote optimal health conditions in its population. In addition, the research contributes to the characterization of the environmental determinants that strengthen the territorial policy and the spatial ordering of productive activities, urban regulations, and identification of the health risk for the population.

\section{Declaration of competing interest}

We declare that we have no significant competing interests including financial or non-financial, professional, or personal interests interfering with the full and objective presentation of the work described in this manuscript.

\section{Acknowledgments}

The research was financed by the Universidad Santo Tomás de Colombia, within the framework of the project entitled Characterization and Mapping of Human Exposure to Particulate Matter in Municipalities with Carboniferous Activity. Case study: Guachetá, Cundinamarca. The code of the project is 181571001, developed by the research group i-Land (Intelligence and Territorial Analysis).

\section{Funding}

The research was funded by the University Santo Tomás.

\section{Author contributions}

Methodology: B.J.S., A.F.S., R.J.S. and L.C.B.B; data acquisition and analysis: B.J.S.,A.F.S.,R.J.S. and L.C.B.B; field work activity: B.J.S. and A.F.S; writing and editing the original manuscript: B.J.S., A.F.S., R.J.S. and L.C.B.B. All authors have read and agreed to the published version of the manuscript.

\section{Data Availability Statement}

The data that support the findings of this study are available on request from the corresponding author

\section{References}

[1] E. Ge and et al., "Differential effects of size-specific particulate matter on emergency department visits for respiratory and cardiovascular diseases in Guangzhou, China," Environmental Pollution, vol. 243, no. Parte A, Dic. 2018. [Online]. Available: https://doi.org/10.1016/j.envpol.2018.08.068

[2] L. A. Rodríguez-Villamizar, N. Y. Rojas-Roa, L. C. Blanco-Becerra, V. M. Herrera-Galindo, and J. A. Fernández-Niño, “Short-Term Effects of Air Pollution on Respiratory and Circulatory Morbidity in Colombia 2011-2014: A Multi-City, Time-Series Analysis," International Journal of Environmental Research and Public Health, vol. 15, no. 8, Jul. 30, 2018. [Online]. Available: https://doi.org/10. 3390/ijerph15081610

[3] R. Jan, R. Roy, S. Yadav, and P. Gursumeeran, “Exposure assessment of children to particulate matter and gaseous species in school environments of Pune, India," Building and Environment, vol. 111, Ene. 2017. [Online]. Available: https://doi.org/10.1016/j.buildenv. 2016.11.008

[4] M. M. Téllez-Rojo and et al., “Children's acute respiratory symptoms associated with $\mathrm{PM}_{2.5}$ estimates in two sequential representative surveys from the Mexico City Metropolitan Area," Environmental Research, vol. 180, Ene. 2020. [Online]. Available: https://doi.org/10. 1016/j.envres.2019.108868

[5] K. H. Kim, E. Kabir, and S. Kabir, "A review on the human health impact of airborne particulate matter," Environment International, vol. 74, Ene. 2015. [Online]. Available: https://doi.org/10.1016/j. envint.2014.10.005 
[6] C. P. Jiménez-Forero, I. T. Zabala, and A. J. Idrovo, "Condiciones de trabajo y morbilidad entre mineros del carbón en Guachetá, Cundinamarca: la mirada de los legos," Biomédica, vol. 35, no. 2, Ago. 2015. [Online]. Available: https://doi.org/10.7705/biomedica. v35i0.2439

[7] C. Doria-Argumedo and J. Fagundo-Castillo, "Niveles de metales en partículas atmosféricas en la zona minera de carbón, norte de Colombia," ITECKNE, vol. 14, no. 2, 2017. [Online]. Available: https://doi.org/10.15332/iteckne.v14i2.1765

[8] E. S. Rodríguez and Y. C. Jiménez, “Análisis del desempeño ambiental de las empresas carboníferas del municipio de Guachetá, Cundinamarca," Undergraduate thesis, Facultad de Ingeniería Civil, Universidad Católica de Colombia, Bogotá, Colombia, 2019. [Online]. Available: https://hdl.handle.net/10983/23470

[9] D. Pérez-Guarumo, "Condiciones de Seguridad Industrial y Procesos de Formalización en Minas de Carbón del Municipio de Guachetá Cundinamarca, Colombia," Undergraduate thesis, Facultad de Relaciones Internacionales, Estrategia y Seguridad, Universidad Militar Nueva Granada, Bogotá, Colombia, 2015. [Online]. Available: https://bit.ly/3h5qX46

[10] P. Oliva and et al. (2001, Ago.) Programa aire puro, monitoreo del aire, manual de laboratorio. Swisscontact. [Online]. Available: http://www.ingenieroambiental. $\mathrm{com} /$ Manual-laboratorio-analisis-aire.pdf

[11] W. Jiao and et al., "Community Air Sensor Network (CAIRSENSE) project: evaluation of low-cost sensor performance in a suburban environment in the southeastern United States," Atmospheric Measurement Techniques, vol. 9, no. 11, Nov. 1, 2016. [Online]. Available: https://doi.org/10.5194/amt-9-5281-2016

[12] J. F. Franco and et al., "Niveles de material particulado en colegios distritales ubicados en vías con alto tráfico vehicular en la ciudad de Bogotá: estudio piloto," Revista Facultad de Ingeniería Universidad de Antioquia, no. 49, May. 26, 2009. [Online]. Available: https://www.redalyc.org/pdf/430/43019324010.pdf

[13] J. Becerra and et al., "Driving commerce to the web-corporate intranets and the internet: Lines blur," Communications Week, vol. 242, Ene. 1, 2020. [Online]. Available: https://doi.org/10.1016/j. jclepro.2019.118420

[14] E. Magaña, J. M. Carrera, and S. Ramos, "Estudio de tendencia de la PM10 y su impacto a la salud en tres zonas metropolitanas de México durante 2005-2009," Kuxulkab', vol. 19, no. 37, Sep. 13, 2019. [Online]. Available: https://doi.org/10.19136/kuxulkab.a19n37.343

[15] A. Arifuddin, J. Jalaludin, and N. Hisamuddin, "Air Pollutants Exposure with Respiratory Symptoms and Lung Function among Primary School Children nearby Heavy Traffic Area in Kajang," Asian Journal Atmospheric Environment, vol. 13, no. 1, Mar. 2019. [Online]. Available: https://doi.org/10.5572/ajae.2019.13.1.021

[16] Y. Zhang and et al., "The association of ambient $\mathrm{pm}_{2.5}$ with school absence and symptoms in schoolchildren: a panel study," Pediatric Research, vol. 84, no. 1, May. 23, 2018. [Online]. Available: https://doi.org/10.1038/s41390-018-0004-1

[17] L. Rodríguez, A. Herrera, H. Castro, J. Niederbacher, and L. Vera, "Incidencia de síntomas respiratorios y su asociación con contaminación atmosférica en preescolares: un análisis multinivel," Cadernos de Saúde Pública, vol. 26, no. 7, Jul. 2010. [Online]. Available: https://doi.org/10.1590/S0102-311X2010000700020

[18] L. Hernández-Flórez and et al., “Contaminación del aire y enfermedad respiratoria en menores de cinco años de bogotá,
2007," Revista salud pública, vol. 15, no. 4, 2013. [Online]. Available: https://www.scielosp.org/pdf/rsap/2013.v15n4/552-565/es

[19] R. Sarmiento, L. Hernández, E. Medina, N. Rodríguez, and J. Reyes, "Síntomas respiratorios asociados con la exposición a la contaminación del aire en cinco localidades de bogotá, 2008-2011, estudio en una cohorte dinámica," Biomédica, vol. 35, no. 2, Ago. 10, 2015. [Online]. Available: https://doi.org/10.7705/biomedica.v35i0. 2445

[20] L. Álvarez and A. Salazar, “Síntomas respiratorios y función pulmonar en niños de 6 a 14 años de edad y su relación con la contaminación por material particulado $\mathrm{PM}_{10}$ en Santa Marta-Colombia," Revista Española de Salud Pública, vol. 87, no. 3, 2013. [Online]. Available: https://scielo.isciii.es/pdf/resp/v87n3/03_ original2.pdf

[21] N. Martins and G. C. da Graça, "Impact of PM2.5 in indoor urban environments: A review," Sustainable Cities and Society, vol. 42, 0ct. 2018. [Online]. Available: https://doi.org/10.1016/j.scs.2018.07.011

[22] T. C. Lewis and et al., "Air pollution and respiratory symptoms among children with asthma: vulnerability by corticosteroid use and residence area," Science of The Total Environment, vol. 448, Mar. 15, 2013. [Online]. Available: https://doi.org/10.1016/j.scitotenv.2012. 11.070

[23] C. Song and et al., "Health burden attributable to ambient $\mathrm{PM}_{2.5}$ in China," Environmental Pollution, vol. 223, Abr. 2017. [Online]. Available: https://doi.org/10.1016/j.envpol.2017.01.060

[24] Y. Gao, E. Y. Chan, L. Li, P. Lau, and T. W. Wong, “Chronic effects of ambient air pollution on respiratory morbidities among Chinese children: a cross-sectional study in Hong Kong," BMC Public Health, vol. 14, no. 1, Feb. 3, 2014. [Online]. Available: https://doi.org/10.1186/1471-2458-14-105

[25] H. T. Lâm and et al., "Increase in asthma and a high prevalence of bronchitis: Results from a population study among adults in urban and rural Vietnam," Respiratory Medicine, vol. 105, no. 2, Feb. 2011. [Online]. Available: https://doi.org/10.1016/j.rmed.2010.10.001

[26] L. Quiroz-Arcentales and et al., "Enfermedad y síntomas respiratorios en niños de cinco municipios carboníferos del Cesar, Colombia," Revista salud pública, vol. 15, no. 1, 2013. [Online]. Available: https://www.scielosp.org/pdf/rsap/2013.v15n1/66-79/es

[27] P. M. Salo and et al., "Respiratory symptoms in relation to residential coal burning and environmental tobacco smoke among early adolescents in Wuhan, China: a cross-sectional study," Environmental Health, vol. 3, no. 1, Dic. 7, 2004. [Online]. Available: https://doi.org/10.1186/1476-069X-3-14

[28] M. Simoni and et al., "Respiratory symptoms/diseases and environmental tobacco smoke (ETS) in never smoker Italian women," Respiratory Medicine, vol. 101, no. 3, Mar. 2007. [Online]. Available: https://doi.org/10.1016/j.rmed.2006.06.021

[29] Y. Lu and et al., "Evidence from SINPHONIE project: Impact of home environmental exposures on respiratory health among school-age children in Romania," Science of The Total Environment, vol. 621, Abr. 15, 2018. [Online]. Available: https://doi.org/10.1016/j.scitotenv. 2017.11.157

[30] A. Builes-Jaramillo, J. Gómez-Bedoya, S. Lopera-Uribe, and V. Fajardo-Castaño, "Hotspots, daily cycles and average daily dose of $\mathrm{PM}_{2.5}$ in a cycling route in Medellin," Revista Facultad de Ingeniería Universidad de Antioquia, no. 96, 2020. [Online]. Available: https://doi.org/10.17533/udea.redin.20191153 